\title{
International Financial Integration, Sovereignty, and Constraints on Macroeconomic Policies
}

\author{
Kenneth Kletzer
}

This paper considers the consequences of international financial market integration for national fiscal and monetary policies that derive from the absence of an international sovereign authority to define and enforce contractual obligations across borders. The sovereign immunity of national governments serves as a fundamental constraint on international finance and is used to derive intertemporal budget constraints for sovereign nations and their governments. It is shown that the appropriate debt limit for a country allows for state-contingent repayment. With non-contingent debt instruments, debt renegotiation occurs in equilibrium with positive probability. A model of tax smoothing is adopted to show how information imperfections lead to conventional bond contracts that are renegotiated when a critical level of indebtedness is reached. Renegotiation is interpreted in terms of nominal and real denominated bonds drawing implications for the intertemporal borrowing constraint for monetary policies, the accumulation of reserve assets, and current account sustainability.

Keywords: International financial integration; Sovereignty; Tax smoothing; Nominal public debt; Monetary policy

JEL Classification: E60, F40, H60 


\section{Introduction}

International financial integration restricts the capacity of national authorities to use fiscal, financial, and monetary policies to influence domestic economic performance. In an integrated financial market, government debt competes for world savings and fiscal authorities do not enjoy a captive supply of domestic savings for financing public expenditures. Lax financial-sector policies can be severely punished by international financial markets, and external real and monetary disturbances impact monetary policymaking. International financial integration can eliminate opportunities for financial repression in liberalizing economies, exposing public finance and monetary policies to the discipline of a competitive capital market. On the other hand, global capital market integration can broaden the base for generating revenues from seigniorage and unanticipated inflation taxes for advanced industrialized economies.

This paper considers the appropriate constraints on national fiscal and monetary policies in an integrated financial market that derive from the absence of an international sovereign authority to define and enforce contractual obligations across borders. International public borrowing is possible to the extent that debt issuers restrain their exercise of sovereign immunity. While sovereign immunity may be waived with regard to debtor assets abroad, it is not waived with regard to domestic policy, legislation, and enforcement. Sovereign immunity protects a debtor government's power to tax sources of income and wealth within national borders. The enforcement of private contracts between parties subject to different national jurisdictions also requires the enlightened self-interest of sovereign governments.

Sovereign immunity is used as a fundamental assumption to derive intertemporal budget constraints for sovereign nations and their governments. The capacity to finance current aggregate consumption, investment, and government expenditures from global savings is determined endogenously given that a national government acts only in the interest of its constituents while recognizing the consequences of its actions for future transactions and international cooperation. Limits on public debt and deficits are derived in a tax-smoothing model by finding an efficient global equilibrium with international financial flows constrained by borrower sovereign immunity and the willing participation of private creditors. The securities issued by sovereigns are also endogenously determined; that is, the completeness or incompleteness of securities markets is determined in self-enforcing equilibria with and without restrictions on the information available to potential creditors.

Securities markets are incomplete in equilibrium. The model shows how contingent securities are required in international financial market equilibrium when all information about the government is public. By contrast, when shocks to the government's objective are not publicly observed, contingent repayments are only needed if outstanding government debt exceeds a threshold. A conclusion of the paper is that conventional bonds that are renegotiated with positive probability only as the government's debt limit is approached support an efficient outcome with private information. In the full information case, payments on conventional bonds would require renegotiation with positive probability every period for any debt level, 
but in the incomplete information model, bonds are renegotiated only when the debt limit is reached. This is consistent with the observation that renegotiations of emerging market debt denominated in foreign currency are infrequent and happen at high debt levels.

A major consideration of this paper is how constraints on government borrowing may impact monetary policymaking. Efficiency requires that public debt repayments be state contingent in a stochastic environment. A line of research beginning with Lucas and Stokey (1983) studies the role of nominal public debt for achieving state-contingent payments with endogenous or exogenous monetary policy. ${ }^{l}$ While several papers (Lucas and Stokey [1983] and Persson and Svensson [1984] in particular) emphasize how denominating public debt in domestic currency creates an inflationary bias for monetary policy, other papers (notably, Bohn [1988, 1990] and Barro [1999, 2003]) emphasize how nominal public debt can increase welfare when the government is restricted to issuing non-contingent (conventional) bonds. ${ }^{2}$ With stochastic expenditures in a simple tax-smoothing model, payments to government liabilities need to be contingent on expenditures in every period in the Lucas and Stokey, and Bohn and Barro models. This suggests the conflict between state contingency and incentives for monetary policy brought out by Lucas and Stokey (1983).

This paper reconsiders the question of nominal debt versus real indexed debt (or foreign currency denominated debt) in the optimal contracting approach with the debt limits derived endogenously from sovereign immunity. A main implication of the literature cited above is that nominal government bonds implement an implicit state-contingent (long-term) contract. Implicit contracts require self-enforcement, and the equilibria discussed below are self-enforcing so that they are time consistent. The introduction of incomplete information in the model implies that unanticipated inflation with nominal debt contracts is only desirable if outstanding debt exceeds a critical threshold. Also, in the optimum, inflation at most eliminates net real interest on nominal bonds.

The two contrasting equilibria bring out constraints on both fiscal and monetary policy. With complete information, government bond borrowing imposes a burden on monetary policy to generate contingent inflation regularly. With private information, unanticipated inflation is required for efficiency with nominal government debt only near the debt limit with adverse shocks. Otherwise, self-enforcing equilibria with nominal public debt work in favor of commitment in monetary policy, particularly to predictable inflation, consistent with much of the recent literature on monetary policy rules.

The renegotiation of foreign currency denominated debt issued by emerging market debtors has been a protracted and costly experience over the years. By issuing bonds denominated in domestic currency, renegotiation can be easily implemented

1. For example, Persson and Svensson (1984), Bohn (1988, 1990), Calvo and Guidotti (1990), Giavazzi and Pagano (1990), Chari, Christiano, and Kehoe (1994), Missale and Blanchard (1994), Aiyagari et al. (2002), and Barro (1999, 2003).

2. Bohn $(1988,1990)$ considers why nominal public debt is predominant in light of the conclusions of Lucas and Stokey (1983) and shows that nominal debt indexation is constrained optimal in a model following Barro (1979). Barro $(1999,2003)$ argues that nominal indexation allows potentially welfare-improving contingent repayment with exogenous stochastic inflation. 
by the debtor, but this requires that national authorities face other costs of generating unanticipated inflation that provide incentives for monetary restraint (to solve the time consistency problem studied by Lucas and Stokey [1983], among many others). For example, the holding of domestic currency debt by constituents can provide a disincentive for the government to inflate. The ease of reducing repayments on domestic currency debt ex post also implies that governments which cannot issue such debt for reputational reasons may hold stocks of foreign nominal public debt in reserve for smoothing aggregate output and consumption. Reserve currency assets provide an instrument for accumulating and decumulating public credit as necessary. However, accumulating and expending reserves is not sufficient to implement an efficient outcome. In equilibrium, a reserve-accumulating country should switch to issuing liabilities subject to default and renegotiation when the lower bound on reserves is reached.

The model of public finance in an open economy under sovereign immunity with complete information is presented first. The model is then extended to allow incomplete information between the government and creditors that motivates the role of conventional non-contingent bonds. The analysis is used to draw implications for constraints on macroeconomic policy, current account sustainability, and the accumulation of reserve assets. The consequences of the derived debt limits for interest rates and relative prices in a decentralized private economy are briefly discussed.

\section{Sovereignty and Public Debt in the Open Economy}

A model of international financial transactions is analyzed in which national governments enjoy sovereign immunity. Sovereign immunity means that national authorities can regulate activities within their jurisdiction through legislation, administration, and judicial enforcement. Foreign governments cannot interfere with economic activities within sovereign boundaries and cannot enforce contractual relationships without the cooperation of national authorities. The enforcement of contracts between the domestic private sector and foreigners within a country depends on the institutional and legal solution chosen by a sovereign government. Sophisticated legal systems may readily enforce contractual obligations of resident debtors on behalf of foreign creditors without being subject to the whims of current authorities. However, such institutions for domestic contract enforcement and the extension of its benefits to foreigners are chosen for the national benefit given incentives of international trade.

More specifically, a sovereign government chooses whether to honor its own obligations, whether to foreign or domestic creditors. The ability of a sovereign to borrow depends upon its willingness to repay. Following the literature on sovereign debt, fiscal authorities choose to repay if doing so is in the national interest, anticipating the consequences of failing to fulfill contractual obligations in equilibrium. ${ }^{3}$

3. Models of sovereign debt based on willingness to pay begin with Eaton and Gersovitz (1981). A still timely and thorough review of country risk is given by Eaton, Gersovitz, and Stiglitz (1986). 
The model presented focuses on the financing of public-sector budget deficits in an integrated international financial market. The focus on public finance is natural, because it is important in international finance and because it encompasses all securities issued publicly or privately that enjoy explicit or implicit government guarantees. Implicit guarantees, in the view of this paper, include the enforcement of private contracts and the protection of domestic debtors by the sovereign's own legal system.

The analysis uses a simple model of a fiscal authority seeking to smooth distortionary taxes over time against random shocks to domestic demand, following Barro (1979). The shocks in the model are stochastic exogenous government expenditures for expositional convenience. These represent preference shocks reflected in the objective function of the sovereign policymaker but can be interpreted as any exogenous shocks to domestic absorption. In the model, fiscal authorities raise tax revenues to make transfers from the domestic private sector to creditors, domestic and foreign. More generally, taxation represents the capacity and willingness of the sovereign to ensure private and public debt repayments. Sovereign borrowing should be interpreted liberally as the issuing of any debt securities that can be held by foreign creditors by any debtor potentially protected by the sovereign.

The model allows for the integration of domestic financial markets with international financial markets. Private parties may be able to accumulate or issue internationally tradable debt or perfect substitutes. Government debt may be held by either domestic or foreign residents, allowing the sovereign to default on its contractual obligations to either or both. Implicitly, bonds are held anonymously so that the government cannot selectively default based on the debt holder's identity.

\section{Deficit Finance and Foreign Borrowing}

In a simple tax-smoothing model, government obligations are met by imposing distortionary taxes. Tax distortions are captured simply by assuming that output is a decreasing and concave function of tax revenues, $Y(T)>0, Y^{\prime}(T) \leq 0, Y^{\prime}(0)=0$, and $Y^{\prime \prime}(T) \leq 0$ for $0 \leq T \leq \bar{T}$, where $\bar{T}>0$ is an upper bound on tax revenues. Authorities seek to maximize the utility of a representative agent given by

$$
U_{t}=u\left(c_{t}\right)+E_{t} \sum_{s=t+1}^{\infty} \beta^{s-t} u\left(c_{s}\right)
$$

with respect to the consumption plan, where $c_{t}=y\left(T_{t}\right)=Y\left(T_{t}\right)-T_{t}$, given the need to finance exogenous government expenditures, $g_{t}$. This simple model should be interpreted as follows. Domestic residents seek to smooth their consumption over time, but some households do not have access to internationally integrated financial markets. A portion of domestic consumption cannot be smoothed by the private sector, so the government smooths this consumption by issuing debt in the integrated financial market. Both domestic and foreign savers can hold domestic government 
debt. Government expenditures, $g_{t}$, are independently and identically distributed over a finite support. Substitution allows the government's objective to be written as

$$
\tilde{U}_{t}=v\left(T_{t}\right)+E_{t} \sum_{s=t+1}^{\infty} \beta^{s-t} v\left(T_{s}\right)
$$

where $v(T)=u(Y(T)-T)$ displays negative and decreasing marginal utility in taxes. ${ }^{4}$ The trade balance is given by

$$
\tau_{t}=Y\left(T_{t}\right)-c_{t}-g_{t}=T_{t}-g_{t}
$$

The government issues securities on a global financial market to finance the primary deficit, $g_{t}-T_{t}$. The present value of all financial claims against the government is given by

$$
w_{t}=T_{t}-g_{t}+E_{t} \sum_{s=t+1}^{\infty} \beta^{s-t}\left(T_{s}-g_{s}\right)
$$

The government can issue new securities to finance current primary deficits or the repayment of retiring debt. Debt holders can trade existing securities on the international financial market. The value of securities issued by the government can be rewritten in the form

$$
w_{t}=-\left(g_{t}-T_{t}\right)+\beta E_{t} w_{t+1}
$$

where $w_{t+1}$ is the value of outstanding debt conditional on the state in date $t+1$.

Any individual creditor purchases government securities willingly in any period. This assumption is expressed by the participation constraints,

$$
w_{t} \geq 0 \text { and } w_{t+1} \geq 0
$$

for all states and dates. That is, tradable securities can only have non-negative market values. This rules out securities for which the expected present value can be negative in some future event, such as pure insurance contracts. The conditional expected present value of current and future primary surpluses of the government is restricted to be non-negative at all dates. The government can only force involuntary payments to it by taxing economic activities within its sovereign domain. It can raise revenue on an integrated financial market by issuing securities that always have non-negative market values.

Another set of constraints is introduced to represent national sovereignty. Sovereign authorities can elect to refuse to honor government-issued debt. The constraint that the government will repay only if repaying is in the national interest at the time payments are due is expressed by another participation constraint. The country can choose to

4. The replacement of a tax-smoothing objective for a consumption-smoothing objective for the representative household is demonstrated in Zhu (1992). 
adopt a pay-as-you-go basis for public finance by defaulting on its current debt and never issuing debt again. The sovereignty constraint is expressed as

$$
v\left(T_{t}\right)+E_{t} \sum_{s=t+1}^{\infty} \beta^{s-t} v\left(T_{s}\right) \geq v\left(g_{t}\right)+E_{t} \sum_{s=t+1}^{\infty} \beta^{s-t} v\left(g_{s}\right)
$$

for all dates and states.

An equilibrium with symmetric information between potential creditors and the authorities of the issuing government is characterized first. In equilibrium, securities will have state-contingent payments. In the case of complete state-contingent markets, only the single constraint,

$$
w_{0}=T_{0}-g_{0}+E_{0} \sum_{t=1}^{\infty} \beta^{t}\left(T_{t}-g_{t}\right) \geq 0,
$$

would need to be imposed. With self-enforcing contracts, the constraint, $w_{t} \geq 0$, needs to be imposed for all dates and states.

The equilibrium is found by maximizing

$$
\begin{aligned}
V_{t} & =v\left(T_{t}\right)-v\left(g_{t}\right)+E_{t} \sum_{s=t+1}^{\infty} \beta^{s-t}\left(v\left(T_{s}\right)-v\left(g_{s}\right)\right) \\
& =v\left(T_{t}\right)-v\left(g_{t}\right)+\beta E_{t} V_{t+1},
\end{aligned}
$$

with respect to the current tax revenue, $T_{t}$, and future repayments, $w_{t+1}$, for each state of nature, subject to the constraints,

$$
\begin{aligned}
& T_{t}-g_{t}+\beta E_{t} w_{t+1} \geq w_{t} \\
& w_{t+1} \geq 0 \text { and } V_{t+1} \geq 0 \text { for each state. }
\end{aligned}
$$

The surplus for the government, $V_{t}$, is a function of the outstanding value of its debt, $V_{t}\left(w_{t}\right) .^{5}$

The solution for a self-enforcing equilibrium is familiar from Thomas and Worrall (1988), Kocherlakota (1996), Kletzer and Wright (2000), and Kehoe and Perri (2002). For this tax-smoothing model, the first-order condition for tax revenues can be derived and is given by

$$
\begin{aligned}
& v^{\prime}\left(T_{t}\right)=v^{\prime}\left(T_{t+1}\right) \text { if } w_{t+1}>0 \text { and } V_{t+1}\left(w_{t+1}\right)>0, \\
& v^{\prime}\left(T_{t}\right)<v^{\prime}\left(T_{t+1}\right)<0 \text { if } w_{t+1}=0,
\end{aligned}
$$

and

5. For the stochastic $g_{t}$ following a Markov chain (including independently and identically distributed $g$ ), this surplus can be written as $V\left(w_{t}, g_{t}\right)$. The model extends immediately to the case in which $g_{t}$ follows a Markov chain. 


$$
v^{\prime}\left(T_{t}\right)>v^{\prime}\left(T_{t+1}\right)<0 \text { if } V_{t+1}\left(w_{t+1}\right)=0 .
$$

The solution for $T_{t+1}$ depends on $g_{t+1}$ and $w_{t}$ (as does $w_{t+1}$ ) and can be written as

$$
T_{t+1}=\theta\left(g_{t}, T_{t}\right),
$$

since $T_{t}$ conveys all information about $w_{t}$.

In equilibrium, taxes are completely smoothed between dates if the participation constraints for neither the government nor its creditors is binding (as in equation [9]). Taxes rise with $g_{t+1}$ if creditors' participation constraints bind (as in inequality [10]), and fall as $g_{t+1}$ declines if the government's participation constraint binds as shown in equation (11). For independently and identically distributed $g_{t}$, taxes and the primary surplus are non-decreasing with government expenditures. These are also increasing with the value of outstanding government obligations, $w_{t}$.

The value of financial claims against the government is state contingent in this equilibrium. As shown by Kletzer and Wright (2000) in a different context, this equilibrium can be implemented using single-period debt contracts with state-contingent non-negative repayments. The amount borrowed by the government at any date $t$ is given by

$$
l_{t}=w_{t}+g_{t}-T_{t},
$$

the sum of outstanding public-sector liabilities at the beginning of period $t$ and primary deficit for period $t$. Repayments in period $t+1$ are given by

$$
R_{t+1}=w_{t+1}
$$

An interpretation of the model is that equilibrium can be implemented through continual renegotiation of standard debt contracts with fixed contractual repayments equal to $\max \left\{w_{t+1}\right\}$. Renegotiation yields actual repayments equal to $w_{t+1} \cdot{ }^{6}$

The constraint on the government in the state-contingent economy differs from the conventional solvency constraint. By allowing for sovereign immunity, in the sense that foreign creditors can only indirectly influence the behavior of national executive, legislative, and judicial authorities by not purchasing assets issued by the country, the country's intertemporal budget constraint is given by

$$
w_{t}=-\left(g_{t}-T_{t}\right)+\beta E_{t} w_{t+1} \geq 0 \text { and } w_{t+1} \geq 0,
$$

and not by the conventional solvency constraint given by

$$
\lim _{s \rightarrow \infty} E_{t} \beta^{s-t} b_{s+1} \leq 0 \text { for all } t \text {, where } \beta b_{s+1}=b_{s}+\left(g_{s}-T_{s}\right) .
$$

6. This interpretation of debt renegotiation as the implementation of an implicit contract was suggested by Grossman and van Huyck (1988). 
The difference is that the conventional solvency constraint requires that the expectation of the present value of the primary surplus be at least as great as the current outstanding debt at all dates,

$$
w_{t}=T_{t}-g_{t}+E_{t} \sum_{s=t+1}^{\infty} \beta^{s-t}\left(T_{s}-g_{s}\right) \geq b_{t}
$$

while sovereign immunity imposes the weaker constraint on borrowing that $w_{t}$ be greater or equal to zero at every date.

The accumulation of credit to foreigners will be constrained by sovereign immunity on the other side of the market. In this model, taxation captures the full capacity of the government to ensure repayment on credit to borrowers subject to its jurisdiction. This includes assets held by the public or private sector. Taxation is a catchall for the capacity and willingness of the sovereign to enforce contractual and legal obligations within its borders, including transfers between private parties ordered by the judicial system to settle private contractual disputes. Government expenditures can be interpreted as both government purchases and transfer payments. The quantity, $g_{t}$, can also be interpreted as a stochastic share of aggregate domestic demand for tradable goods that cannot be completely smoothed on international financial markets by households and firms.

In equilibrium, the willingness of bondholders to purchase outstanding debt and accept new debt issues constrains the capacity of the government to smooth the distortionary cost of taxation. Incomplete smoothing arises because the sovereign only services its debt if doing so is in its own best interest. With complete information, state-contingent repayments may be implemented through renegotiation where renegotiation is just the playing out of an implicit state-contingent contract. Asymmetric information about the government's willingness to repay debt can lead to incomplete markets or costly renegotiation.

\section{Incomplete Information and Bond Lending}

The complete information case implies that we should observe a rich set of statecontingent securities or very frequent international debt renegotiation. Asymmetric information between debtors and creditors leads to an incomplete set of statecontingent securities. A simple assumption is that $g_{t}$ is observed by national authorities but can never be observed by creditors. The variable, $g_{t}$ can be interpreted as an unobserved taste shock in the government's objective. One interpretation of this assumption is that national authorities are better informed of their capacity to transfer resources from the domestic private sector to creditors. Those who have achieved political power in a country are likely to know more about the willingness of residents to pay taxes for debt repayment than are individual bondholders or foreign authorities.

The assumption that shocks to expenditures are only observed by the borrowing government requires that equilibrium payments be incentive compatible for the 
government. ${ }^{7}$ In an incentive-compatible equilibrium, the government will reveal the correct realization of $g_{t}$ to creditors by its current choice of the primary deficit, $g_{t}-T_{t}$, which is observed by creditors. The separate components, $g_{t}$ and $T_{t}$, are private information. The gains from tax smoothing suggest that higher reported expenditures should be associated with higher primary deficits. In the complete information case, current repayments and new borrowing can be conditioned separately on the publicly observable state, $g_{t}$. With incomplete information, incentive compatibility requires that the government cannot pay less when $g_{t}$ is high without repaying more in the future. Otherwise, the government could falsely report high expenditures to lower the present value of its net repayments. In an incentivecompatible equilibrium, a favorable shock (lower $g_{t}$ ) should lead to a larger current net repayment (a larger primary surplus) and lower future repayments.

Under private information, an equilibrium is found by maximizing the expected value of government liabilities, $W_{t}=E_{t-1} w_{t}$, given a constraint set that includes the incentive-compatibility condition for the government. The expected future surplus for the government, $E_{t} V_{t+1}$, can be written as a function of the reported current state, denoted $\hat{g}_{t}$, and the value of future repayments to creditors, $W_{t+1}$. Current taxes should also be a function of the reported state. The incentive-compatibility condition requires authorities to be at least as well off reporting the actual state, $g_{t}$, as reporting any other state. It is written as

$$
V_{t}\left(g_{t}, g_{t}\right) \geq V_{t}\left(g_{t}, \hat{g}_{t}\right)
$$

for each state $g_{t}$ and all possible $\hat{g}_{t}$, where

$$
V_{t}\left(g_{t}, \hat{g}_{t}\right) \equiv v\left(T_{t}\left(\hat{g}_{t}\right)\right)-v\left(g_{t}\right)+\beta E_{t} V_{t+1}\left(\hat{g}_{t}\right) .^{8}
$$

The properties of incentive-compatible equilibrium with commitment on one or both sides of the market are well known (for the difficult one-sided commitment case, see Thomas and Worrall [1990]). While incentive-compatible solutions tend to be complicated, allowing a continuous and bounded support for the shock $g_{t}$ simplifies things greatly. ${ }^{9}$ Let the distribution of expenditure shocks have a continuous density over a fixed interval $\left(\left[g^{\min }, g^{\max }\right]\right.$ where $\left.0<g^{\min }<g^{\max }\right)$. In the case of full commitment (no participation constraints), the incentive-compatible equilibrium is supported by conventional non-contingent bond contracts. The expected present value of government liabilities,

$$
W_{t}=T_{t}-g_{t}+\beta W_{t+1},
$$

7. Atkeson (1991) introduces asymmetric information in a repeated moral hazard model of sovereign debt with one-sided commitment. Kletzer (2005) considers bond contracts with no observability of debtor income in a model with two-sided non-commitment.

8. The time subscripts on the functions reflects dependence on ex ante surplus, $E_{t-1} V_{t}$.

9. The demonstration that standard debt contracts with bankruptcy are optimal incentive-compatible contracts is due to Townsend (1979). In that model and others, debtor income is observable at a cost. Cole and Kocherlakota (2001) implicitly demonstrate bond contracting with no observability in a model with hidden savings and no self-enforcement constraints. 
does not depend on the current shock, $g_{t}$. This is the conventional budget identity for bond borrowing. Since the discounted level of the future debt, $\beta W_{t+1}$, varies one for one with the primary surplus, the government has no incentive to misrepresent its current state. The first-order condition for tax smoothing is

$$
v^{\prime}\left(T_{t}\right)=E_{t} v^{\prime}\left(T_{t+1}\right)
$$

The solution without participation constraints parallels equilibrium for self-insurance in the permanent income model. ${ }^{10}$

The participation constraints for bondholders and for the sovereign remain

$$
w_{t+1} \geq 0 \text { and } V_{t+1} \geq 0 \text {, }
$$

respectively. If neither of these constraints binds in any possible state, $g_{t+1}$, then the first-order condition (18) holds. If the government's participation constraint binds for some states, then the first-order condition becomes

$$
v^{\prime}\left(T_{t}\right) \leq E_{t} v^{\prime}\left(T_{t+1}\right)<0
$$

In this case, the government's primary surplus is constrained at time $t$ in state $g_{t}$ by its willingness to raise taxes to make repayments in some states at time $t+1$. When the participation constraints hold for the government's creditors, the first-order condition is given by

$$
v^{\prime}\left(T_{t}\right) \geq E_{t} v^{\prime}\left(T_{t+1}\right)
$$

In this case, the debt limit for the government is reached with positive probability.

The equilibrium when the sovereignty constraint for the government binds helps us to understand the renegotiation of conventional debt contracts issued by sovereigns. When participation constraints are not binding, equilibrium borrowing and repayment are implemented by conventional non-contingent single-period debt contracts. When the sovereignty constraint is binding with positive probability in the next period, the continuation surplus for the government, $E_{t} V_{t+1}$, equals its lowest possible value, which is zero. Therefore, in any state $g_{t}$ that

$$
v^{\prime}\left(T_{t}\right)<E_{t} v^{\prime}\left(T_{t+1}\right)
$$

the government's continuation surplus must be zero. Otherwise, taxes could be smoothed more by reducing current taxes, $T_{t}$, and increasing the debt carried into the next period (that is, lowering the continuation surplus, $\left.E_{t} V_{t+1}\right)$. The present value of outstanding debt is maximized when the government's constraint binds. The debt

10. The model implicitly assumes no global constraints, and this first-order condition implies convergence toward a steady state in which taxes are zero and the interest on government credit covers the upper bound for expenditures. With risk-averse counterparts, the steady-state gross interest rate, $R$, would be smaller than $\beta^{-1}$ and the first-order condition would become $v^{\prime}\left(T_{t}\right)=R \beta E_{t} v^{\prime}\left(T_{t+1}\right)$. 
limit equals the expected surplus for creditors, $W_{t+1}$, when the expected surplus for the government $E_{t} V_{t+1}$ equals zero. The debt limit is denoted $\bar{W}{ }^{l l}$ Incentive compatibility requires that the primary deficit be the same for any state such that inequality (21) holds. If this were not true, then the government could increase its primary deficit without increasing its debt. Whenever the inequality (21) holds in a period, the value of outstanding debt is $\bar{W}$ in the next period.

At the debt limit, taxes are a function of the current state and, naturally, at their highest level in equilibrium. Let $\hat{T}\left(g_{t}\right)$ be the maximum tax revenue collected in state $g_{t}$ in equilibrium. At the debt limit, expected marginal utility, $E_{t-1} v^{\prime}\left(\hat{T}\left(g_{t}\right)\right)$, is a constant if shocks are independently and identically distributed. In this case, there must be a pivotal state, $\bar{g}$, such that inequality (21) holds for expenditure shocks greater than $\bar{g}$. In these states, the primary surplus will equal zero because the debt cannot rise above the limit so that taxes equal expenditures, $\hat{T}\left(g_{t}\right)=g_{t}$, for $g_{t} \geq \bar{g}$. The pivotal state is determined by

$$
v^{\prime}(\bar{g})=E v^{\prime}\left(\hat{T}\left(g_{t}\right)\right)
$$

for $g^{\min }<\bar{g}<g^{\max }$. For expenditure states below $\bar{g}$, the government runs a primary surplus and its debt falls (so that it has an incentive to run a primary surplus).

As the government's debt rises to the debt limit, it follows the standard identity,

$$
\beta W_{t+1}=W_{t}+\left(g_{t}-T_{t}\right)
$$

until

$$
v^{\prime}\left(g^{\max }\right)<E v^{\prime}\left(\hat{T}\left(g_{t}\right)\right)
$$

(recall that $g^{\max }$ is the largest shock to expenditures). For shocks such that the inequality (21) holds, the primary deficit can be positive but must satisfy

$$
\beta \bar{W}=W_{t}+\left(g_{t}-T_{t}\right)
$$

In these circumstances, the primary deficit is independent of expenditures and current taxes are given by

$$
T_{t}=W_{t}-\beta \bar{W}+g_{t} .
$$

Therefore, debt rises from $W_{t}<\bar{W}$ to $\bar{W}$ in period $t+1$ if the shock at date $t$ is equal to or greater than $\hat{g}\left(W_{t}\right)$ which is determined by the condition

$$
v^{\prime}\left(W_{t}-\beta \bar{W}+\hat{g}\left(W_{t}\right)\right)=E v^{\prime}\left(\hat{T}\left(g_{t}\right)\right) .
$$

11. The debt limit $\bar{W}$ is determined endogenously by the condition,

$$
v\left(\hat{T}\left(g_{t}\right)\right)-v\left(g_{t}\right)+\beta E_{t} V_{t+1}=0,
$$

and the inequality (21), which holds with equality for $E_{t} V_{t+1}>0$. 
Another critical debt level, $\widetilde{W}$, can be defined using the first-order condition as

$$
v^{\prime}\left(\widetilde{W}-\beta \bar{W}+g^{\max }\right)=E v^{\prime}\left(\hat{T}\left(g_{t}\right)\right)
$$

If the current debt, $W_{t}$, is less than $\widetilde{W}$, then debt the next period, $W_{t+1}$, remains below the debt limit with certainty. But if the current debt is above the critical level, $\widetilde{W}$, then the debt limit will be reached in one period with the probability that $g_{t} \geq \hat{g}\left(W_{t}\right)$. This probability rises with current outstanding debt in the interval, $\widetilde{W} \leq W_{t} \leq \bar{W}$, as $\hat{g}\left(W_{t}\right)$ decreases from $g^{\max }$ to $\bar{g}$ as $W_{t}$ increases. For $g_{t} \geq \hat{g}\left(W_{t}\right)$, the primary deficit equals $\beta \bar{W}-W_{t}$. For $g_{t}<\hat{g}\left(W_{t}\right)$, the primary deficit is decreasing in the expenditure shock and must be in surplus for low expenditure shocks.

If the debt is below the critical level, $\widetilde{W}$, public debt follows conventional debt dynamics given and repayments are not state contingent. The ex post value of the debt, $w_{t}$, is the same as the ex ante expected value, $W_{t}$. The real rate of interest on single-period bonds is equal to the riskless rate equal to the discount rate, $\rho=(1-\beta) / \beta$. When the debt level is exceeds the critical level, the present value of outstanding bonds varies with the expenditure shock. The return to single-period bonds is risky. Past the critical level, the present value of public debt satisfies

$$
W_{t}=E_{t-1}\left[\left(T_{t}-g_{t}\right)+\beta W_{t+1}\right]
$$

rather than

$$
W_{t}=\left(T_{t}-g_{t}\right)+\beta W_{t+1},
$$

because where $w_{t}=\left(T_{t}-g_{t}\right)+\beta W_{t+1}$ is state dependent. The single-period budget identity can be rewritten as

$$
W_{t+1}=\left(1+r_{t+1}\right)\left[W_{t}+\left(g_{t}-T_{t}\right)\right]
$$

where $r_{t+1}$ is the ex post yield, which is stochastic if debt exceeds the critical level and equal to $\rho$ if debt is below the critical level. For example, if the debt limit has already been reached, the rate of return is zero for adverse shocks because

$$
\bar{W}=\left(1+r_{t+1}\right)\left[\bar{W}+\left(g_{t}-T_{t}\right)\right]=\left(1+r_{t+1}\right) \bar{W} \text { for } g_{t}>\bar{g} \text {. }
$$

For $g_{t}$ less than $\bar{g}$, the yield is positive and falls with higher expenditures. Combining equations (26) and (27) leads to

$$
\rho\left(W_{t}+E_{t-1}\left(g_{t}-T_{t}\right)\right)=W_{t} E_{t-1} r_{t}+E_{t-1}\left[r_{t+1}\left(g_{t}-T_{t}\right)\right]
$$

implying that the actual return exceeds the discount rate for low expenditure shocks.

The equilibrium under incomplete information is implemented by one-period contracts that are only state contingent when the present value of outstanding government obligations is above a threshold. It could be implemented using standard 
one-period debt contracts if these can be costlessly renegotiated in some events. Renegotiation needs to occur with positive probability only when the debt level exceeds the critical level. Under short-term bonds subject to renegotiated repayments, the interest premium on public debt rises above the discount rate after the debt reaches the critical threshold. In the model, creditors are risk neutral or, equivalently, renegotiation risk is uncorrelated with global market risk. Extending the model to allow for risk-averse creditors would yield a risk premium on short-maturity debt that only turns positive when the critical level is attained.

The lowest single-period ex post net yield on bonds is zero. At the debt limit, bondholders lose net interest with an adverse shock but not bond principal. This contrasts with the complete information case in which the gross return to creditors is zero in the worst state when tax smoothing is incomplete. ${ }^{I 2}$ Renegotiation is also an infrequent event in the bond lending case.

\section{Debt Limits and the Government's Budget Constraint}

The debt limit derived for the tax-smoothing model under sovereign immunity is not the same as the conventional debt limit imposed in most models of government borrowing. In the model with private information, government securities have noncontingent repayments unless the sovereignty constraints may bind with positive probability before maturity. A natural interpretation is that equilibrium borrowing and lending follow an implicit contract guided by standard non-contingent debt instruments. Contingent repayments are made through renegotiation of the net interest on conventional bonds issued at interest rates that include a positive risk premium only when the debt exceeds the critical level. Alternatively, an explicit state-contingent contract would specify contingent repayments only when the debt is above the same threshold.

Imposing a conventional solvency constraint on bond borrowing does not allow constrained efficient equilibrium tax smoothing in the presence of sovereign immunity. The conventional approach, for example as followed by Aiyagari (1994) and others, sets an upper bound on outstanding public debt, $b_{t}$, given by

$$
b_{t} \leq \frac{\bar{s}}{\rho}
$$

where $\bar{s}$ is the largest primary surplus sustainable in equilibrium in all possible states and $\rho$ is the discount rate. This ensures that non-contingent debt will be repaid in all events. An equilibrium for the tax-smoothing model can be derived adding the restriction that only non-contingent securities can be issued by the borrower. ${ }^{13}$ Restricting contracts to be non-contingent in all events reduces the set of securities that can be used in equilibrium for the tax-smoothing model under private information, since it eliminates securities that were needed to implement an efficient solution. Doing

12. This is equivalent to the incomplete consumption-smoothing case in Thomas and Worrall (1988), Kocherlakota (1996), and Kletzer and Wright (2000).

13. Two papers that endogenize the debt limit but place exogenous constraints on contracts are Aiyagari (1995) and Aiyagari et al. (2002). 
so must lead to a lower debt limit than the limit, $\bar{W}$, derived above and to less smoothing of taxes. Here, sovereign immunity is a fundamental and the set of securities is endogenous. In the conventional model, the form of securities and contract enforcement are taken as exogenous.

\section{Nominal Debt, Renegotiation, and Debt Limits}

The suggestion by Bohn (1988), Barro (2003), and others that issuing public debt in domestic currency units allows state-contingent real repayments on standard bonds was made in the context of complete information models. In those models, non-contingent bond contracts do not implement the constrained optimum, but non-contingent nominal bonds and unanticipated inflation can generate the required state-contingent real payments to bondholders. ${ }^{14}$ In this model of tax smoothing with incomplete information, nominal debt and unanticipated inflation can serve the same purpose of allowing state-contingent real payments with standard noncontingent securities. An important difference is that state-contingent repayments are only required in a constrained optimum in some events: those that lead to outstanding public debt above the critical threshold. In complete information models, such as Bohn (1988), unanticipated changes in the inflation rate need to be frequent to implement the optimum. In this model, inflationary surprises should only occur in periods of high outstanding debt and high expenditure shocks. These are events in which repayment difficulties forcing debt renegotiation would occur if non-contingent bonds are issued in real terms.

The introduction of nominal debt requires adding money and one-period nominal debt with fixed money interest to the model. Formally, real balances can be introduced as an argument in the utility function for domestic residents in an additively separable way. This gives a standard relationship between current consumption, the nominal stock of money, the nominal interest rate, and the price level. For example, for logarithmic utility in real balances, real balance demand will be given by

$$
\frac{M_{t}}{p_{t}}=u^{\prime}\left(c_{t}\right) \kappa \frac{1+i_{t+1}}{i_{t+1}}
$$

for a constant $\kappa$ and nominal interest rate $i_{t+1}$. Outstanding nominal debt is given by $B_{t}=p_{t} W_{t}$, so that nominal debt evolves according to

$$
B_{t+1}=\left(1+i_{t+1}\right)\left[B_{t}+p_{t}\left(g_{t}-T_{t}\right)\right]
$$

and real debt follows

$$
W_{t+1}=\frac{p_{t}}{p_{t+1}}\left(1+i_{t+1}\right)\left[W_{t}+\left(g_{t}-T_{t}\right)\right]
$$

14. Barro (2003) does not model optimal fiscal and monetary policy with nominal debt, but instead argues that nominal debt with independently determined inflation allows state contingency that may be welfare improving. Bohn $(1988,1990)$ considers optimal policy without endogenizing debt limits. 
If inflation is stochastic, then the change in the real value of the debt is also stochastic. Replication of the equilibrium with sovereign bonds requires that the real return to nominal bonds equals the equilibrium yield for real bonds,

$$
\frac{p_{t}}{p_{t+1}}\left(1+i_{t+1}\right)=1+r_{t+1} \text {. }
$$

When the real value of the debt is less than the critical level, the Fisher interest parity condition,

$$
\left(1+i_{t+1}\right)=\frac{p_{t+1}^{e}}{p_{t}} \beta,
$$

holds, where actual inflation must equal expected inflation to support the constrained optimum with non-contingent nominal interest rate bonds. When the debt is above the critical level, then actual inflation should deviate from expected inflation to satisfy equation (34). State-contingent fluctuations in the ex post real yield on bonds could be accomplished with unanticipated inflation brought about by surprise money supply growth in this framework. This suggests that issuing debt denominated in domestic currency could allow the implementation of the constrained efficient equilibrium without explicit state-contingent government securities or debt renegotiation when the debt exceeds the critical threshold. By contrast, bonds indexed in commodity units or in terms of the currency of another country would need to be renegotiated and restructured explicitly when the debt limit is reached, perhaps following outright default.

Achieving state contingency through unanticipated inflation with domestic currency debt raises the problem of how to enforce an implicit contract. That is, what keeps the debtor from reducing the real value of its debt too much through unanticipated inflation? In the complete information model of sovereign debt, Kletzer and Wright (2000) demonstrate how equilibrium state-contingent loans can be enforced by market participants. In their model, deviation from the implicit contract constitutes default and results in a short-lived embargo on new real resource inflows until the debtor makes a payment to its creditors that eliminates the gain from default. ${ }^{15}$ The proof that credit markets are sustainable without interfering with sovereign immunity can be extended readily to the tax-smoothing model with asymmetric information. However, the case of nominal debt contracts with unanticipated inflation requires more interpretation.

Suppose that a sovereign with outstanding debt denominated in the sovereign's own currency increases the money supply by more than is mandated by equation (34). This reduces the real value of the outstanding stock of debt, deviating from the equilibrium expected by bondholders. The punishment needed must lower the debtor's continuation surplus, $E_{t} V_{t+1}$, to at least offset the increase in the debtor's current gain from generating too much inflation. This can be accomplished by issuing new nominally indexed debt or issuing new debt that is real indexed or in

15. Kletzer and Wright (2000) prove that a coalition-proof equilibrium exists. Wright (2001) proves that the result carries over when creditors can commit but are oligopolistic for a less strict definition of coalition-proofness. 
another currency. In the first case, the existing debt may be refinanced by issuing new bonds denominated in the debtor's currency at nominal interest rates exceeding the required equilibrium real rate of return by an inflation rate that is a credible upper bound for the sovereign's currency. That is, excessive money supply growth at time $t-1$ results in inflation, $p_{t}^{\prime} / p_{t-1}$, reducing the value of nominal debt claims to $W_{t}^{\prime}$ from what was expected, $W_{t}$,

$$
W_{t}>W_{t}^{\prime}=\frac{p_{t-1}}{p_{t}^{\prime}}\left(1+i_{t}\right)\left[W_{t-1}+\left(g_{t-1}-T_{t-1}\right)\right]
$$

The terms of the new issues, including the primary surplus at time $t$, would need to satisfy

$$
W_{t+1} \leq \frac{p_{t}^{\prime}}{p_{t+1}^{\prime}}\left(1+i_{t+1}^{\prime \prime}\right)\left[W_{t}^{\prime}-s_{t}^{\prime \prime}\right],
$$

where primes denote the deviation from the equilibrium and double primes the market response. This response ensures no gain from deviation. This notion hinges on the credibility of an upper bound on the inflation rate for the sovereign issuer. If the government suffers other losses from higher inflation (as in many models of monetary policy), then a credible bound on inflation is possible. ${ }^{16}$ If the government is not inflation averse, then reversion to foreign currency bonds remains a punishment strategy. It may be the case that the government does not take account of the welfare of its domestic creditors or that foreign bondholders do not know the government's objectives (there are additional asymmetries of information). New debt accomplishes the same purpose as condition (36) by satisfying the constraint

$$
W_{t+1} \leq\left(1+r_{t+1}^{\prime \prime}\right)\left[W_{t}^{\prime}-s_{t}^{\prime \prime}\right] \text {, }
$$

where the real interest rate and primary surplus leave the borrower with no gain for devaluing the outstanding debt the previous period. ${ }^{17}$

\section{Implications for Foreign Borrowing and Reserves}

Financial assets traded across borders are subject to sovereign risk whether issued by the government or by domestic private debtors. The tax-smoothing model can be interpreted as a model of international borrowing by reinterpreting the primary deficit as the trade balance and outstanding debt as the net foreign liabilities of the economy. The current account balance measured in tradable goods is given by

16. A natural explanation of how a currency becomes a reserve currency is that a large share of government debt is held by constituents of the issuing government. An early version of such a model is Buiter and Eaton (1985).

17. As in deviations from equilibrium payment with contingent contracts and sovereign risk, holders of debt at time $t-1$ do suffer capital losses. The borrower cannot gain by deviating from the implicit contract in perfect equilibrium (see Kletzer and Wright [2000]). 


$$
W_{t+1}-W_{t}=r_{t}\left(W_{t}+g_{t}-T_{t}\right) .
$$

The conventional solvency constraint is again inconsistent with a constrained optimum with internationally integrated financial markets. In equilibrium with private information, repayments only need to be state contingent once the debt exceeds the critical threshold. When external debt is above the critical level, payments on nominal non-contingent bonds can be reduced through surprise inflation, but payments on foreign currency denominated bonds must be renegotiated to achieve the required state contingency. For the case of foreign currency denominated debt, debt renegotiation can be protracted and costly. Any such additional costs would need to be acknowledged when interpreting the sovereignty constraint. ${ }^{18}$

The capacity to issue debt denominated in the sovereign's currency creates a natural way to implement state-contingent repayments, but relies on the costs of unanticipated inflation to the sovereign's own objectives. This implies that internationally traded debt will be denominated in the currencies of nations whose governments face high domestic costs of inflating away the value of outstanding nominally indexed public debt.

International reserve assets denominated in foreign currencies can play a role in interpreting equilibrium in the sovereign borrowing model. Interest-bearing assets issued by the reserve currency country can be accumulated by a government that cannot issue debt in its own currency through capital inflows generated either by a current account surplus or foreign investment. These assets can be used to finance future current account deficits.

In the model, only changes in the net debt or credit of the government are determined. Whether the country is a net issuer of bonds or holder of the debt of other sovereigns is indeterminate. The model can be used to consider a government that smooths taxes against stochastic domestic shocks by accumulating and decumulating international assets denominated in a reserve currency. The reserve-accumulating government can solve the problem of maximizing its surplus with respect to current taxes and future reserves,

$$
V_{t}\left(a_{t}\right)=\max \left\{v\left(T_{t}\right)-v\left(g_{t}\right)+\beta E_{t} V_{t+1}\left(a_{t+1}\right)\right\},
$$

where reserve assets, $a$, follow the conventional identity

$$
\beta a_{t+1}=a_{t}+\left(T_{t}-g_{t}\right) .
$$

This is a storage problem with possible stock outs when reserves reach zero with positive probability in the next period. The first-order condition is still given by inequality (19),

$$
v^{\prime}\left(T_{t}\right) \leq E_{t} v^{\prime}\left(T_{t+1}\right) .
$$

18. An explicit model of protracted and costly debt restructurings based on models of debt renegotiation is given by Kletzer (2003). 
When reserves are sufficiently low, these go to zero (or an arbitrary lower bound) in high-expenditure states. In low-expenditure states, the government smooths taxes by accumulating more reserves because

$$
v^{\prime}\left(T_{t}\right)=E_{t} v^{\prime}\left(T_{t+1}\right)
$$

in favorable states. However, positive savings in non-contingent bonds yields a positive surplus,

$$
v\left(T_{t}\right)-v\left(g_{t}\right)+\beta E_{t} V_{t+1}\left(a_{t+1}\right)>0,
$$

when $a_{t}=0$ and $a_{t+1}=\beta^{-1}\left(T_{t}-g_{t}\right)$ in these states.

To achieve the constrained optimum, more surplus needs to be extracted when government credit goes to zero. The government must also borrow in addition to saving through the accumulation of reserve assets to efficiently smooth taxes under sovereign immunity. Therefore, a government that cannot sell securities denominated in its own currency internationally should issue foreign currency (or real-indexed) liabilities. These liabilities will be subject to renegotiation in a constrained efficient equilibrium.

\section{Decentralized Equilibrium and the Current Account}

Approaching the debt limit, the trade deficit must eventually decrease and turn to surplus. In a decentralized economy, this is achieved by movements in real interest rates and the relative prices of goods and services. Marginal utility, $v^{\prime}(T)$, can be interpreted as the marginal utility of repaying an amount $T$ by a representative household (so that $u^{\prime}\left(c_{t}\right)=-v^{\prime}\left(T_{t}\right)$ ). For a sufficiently adverse shock with net external debt above the critical level, the first-order condition is given by

$$
u^{\prime}\left(c_{t}\right) \geq E_{t} u^{\prime}\left(c_{t+1}\right)
$$

The domestic real interest rate for the decentralized economy, $r_{t+1}$, is determined by

$$
u^{\prime}\left(c_{t}\right)=\beta\left(1+r_{t+1}\right) E_{t} u^{\prime}\left(c_{t+1}\right)
$$

The real interest rate rises above the discount rate as external debt passes the critical level. The increase in the interest rate induces a rise in domestic saving that reverses the trade balance and current account when the debt limit is reached.

With tradable and non-tradable goods, the real exchange rate will also respond as debt passes the critical level for an endowment economy. The contraction in tradable goods consumption will be determined by the first-order conditions,

$$
\frac{u_{1}^{\prime}\left(c_{t}^{T}, c_{t}^{N}\right)}{u_{2}^{\prime}\left(c_{t}^{T}, c_{t}^{N}\right)}=\frac{p_{t}^{T}}{p_{t}^{N}} \equiv q_{t},
$$


and

$$
u_{1}^{\prime}\left(c_{t}^{T}, c_{t}^{N}\right)=\beta\left(1+r_{t+1}\right) E_{t} u_{1}^{\prime}\left(c_{t+1}^{T}, c_{t+1}^{N}\right)
$$

and the equilibrium conditions,

$$
c_{t}^{N}=y_{t}^{N}, c_{t+1}^{N}=y_{t+1}^{N} \text {, and } W_{t}=c_{t}^{T}-y_{t}^{T}+\beta W_{t+1},
$$

where the real interest rate, $r_{t+1}$, and net foreign assets, $W_{t}$, are in terms of tradable goods. Real exchange and interest rate changes will depend on the elasticities of substitution between goods and over time.

\section{Conclusion}

The capacity of sovereigns to choose whether to honor public debts or enforce private debts inhibits the ability of foreign creditors to enforce contractual obligations in international finance. It also restricts the access that countries have to international financial markets, constraining the scope for national policymaking. Restrictions on sovereign borrowing naturally lead to constraints on net external asset positions and current account dynamics, as well as public-sector budget deficits and debt. The model of sovereign borrowing adopted here stresses the endogeneity of borrowing limits to the objectives of national governments and domestic and foreign fundamentals.

The analysis shows that conventional debt limits based on certain payment of bonds may not lead to the equilibrium intertemporal constraints on national policymakers. Endogenous constraints derived under information asymmetries that motivate conventional bond contracts require that the repayment on sovereign bonds become state contingent as debt limits are approached. Renegotiation of the terms of repayment is necessary if bonds are issued with non-contingent repayments in real terms. If bonds are issued with non-contingent repayments in terms of the issuer's own currency, then inflationary capital losses for bondholders are consistent with the constrained efficiency of equilibrium.

The usefulness of nominal public debt for achieving contingent repayments with a tax-smoothing motive under uncertainty is reconsidered by comparing equilibrium with and without private information for the debtor. In the complete information case (corresponding to previous models, for example, Bohn [1988] and Barro [2003], with conventional solvency constraints), optimal inflation is stochastic each period. This conflicts with the commitment in monetary policymaking needed to resolve timeconsistency problems. The incomplete information model implies that debt reduction through unanticipated inflation should not be an everyday contingency. Debt reduction should be restricted to times in which outstanding debt exceeds a critical threshold and to holding the debt to the debt limit. Therefore, the denomination of public debt in domestic currency does not necessarily conflict with time-consistent monetary policy. Indeed, inflation targeting is not in conflict with optimal nominal debt when debt constraints are not binding. High debt does constrain monetary 
policy by providing incentives to deliver unanticipated inflation, but credibility in fiscal policy (the reputational equilibrium is supportable by credible punishments) limits the erosion of the real value of debt during a crisis.

The convenience of one-sided renegotiation of the real terms of repayment with monetary expansion will be an option for governments that are sufficiently averse to unanticipated inflation. Inflation aversion can be associated with government objectives that weight the welfare of domestic holders of nominal debt (including noninterest-bearing money). Governments lacking credibility for inflationary restraint or fiscal discipline may not be able to issue debt denominated in domestic currency. With complete information, contingent repayment is needed in all periods in the optimum implying frequent, indeed constant, renegotiation. With incomplete information, debt renegotiation is required only when the debt limit is reached. This corresponds to empirical experience. Debt restructurings are infrequent, the debt to GDP ratio is a strong predictor of default and renegotiation, and overwhelmingly emerging market public debt is issued as foreign currency non-contingent bonds or loans.

Constraints on monetary and fiscal policy derive from the need to enforce reputational equilibria consequent to issuing debt denominated in national currency units on an open market in the framework of this paper. Monetary expansions and contractions will be constrained by the level of outstanding nominal debt in the extension to a reputational equilibrium in both monetary and fiscal policy. The role of seigniorage revenue was not included, because no new issues arise from sovereign immunity. The constraints on fiscal policies, and, more generally, current account balances, are independent of monetary policy in the model because full price flexibility was assumed. However, introducing a role for monetary policy through nominal price rigidity and imperfect competition will not change the implications if creditors have symmetric knowledge of the objectives of national policymakers and the fundamentals that motivate monetary expansion.

\section{References}

Aiyagari, S. R., "Uninsured Idiosyncratic Risk and Aggregate Savings," Quarterly Journal of Economics, 109 (3), 1994, pp. 659-684.

- "Optimal Capital Income Taxation with Incomplete Markets and Borrowing Constraints," Journal of Political Economy, 103 (6), 1995, pp. 1158-1175.

_ A. Marcet, T. Sargent, and J. Seppälä, "Optimal Taxation without State-Contingent Debt," Journal of Political Economy, 110 (6), 2002, pp. 1220-1254.

Atkeson, A., "International Lending with Moral Hazard and Risk of Repudiation," Econometrica, 59, 1991, pp. 1069-1089.

Barro, R. J., "On the Determination of Public Debt," Journal of Political Economy, 87, 1979, pp. 940-971.

__, "Notes on Optimal Debt Management," Journal of Applied Economics, 2 (2), 1999, pp. 281-289.

- "Optimal Management of Indexed and Nominal Debt," Annals of Economics and Finance, 4, 2003, pp. 1-15.

Bohn, H., "Why Do We Have Nominal Government Debt?" Journal of Monetary Economics, 21, 1988, pp. 127-140.

"Tax Smoothing with Financial Instruments," American Economic Review, 80 (5), 1990, pp. 1217-1230. 
Buiter, W., and J. Eaton, "Policy Decentralization and Exchange Rate Management in Interdependent Economies," in J. S. Bhandari, ed. Exchange Rate Management under Uncertainty, Cambridge, Massachusetts: MIT Press, 1985, pp. 31-54.

Calvo, G., and P. Guidotti, "Indexation and Maturity of Government Bonds: An Exploratory Model," in R. Dornbusch and M. Draghi, eds. Public Debt Management: Theory and History, Cambridge: Cambridge University Press, 1990.

Chari, V. V., L. J. Christiano, and P. J. Kehoe, "Optimal Fiscal Policy in a Business Cycle Model," Journal of Political Economy, 102, 1994, pp. 617-652.

Cole, H., and N. Kocherlakota, "Efficient Allocations with Hidden Income and Hidden Storage," Review of Economic Studies, 68 (3), 2001, pp. 523-542.

Eaton, J., and M. Gersovitz, "Debt with Potential Repudiation: Theory and Estimation," Review of Economic Studies, 48, 1981, pp. 289-309.

— - , and J. E. Stiglitz, "The Pure Theory of Country Risk," European Economic Review, 30, 1986, pp. 481-513.

Giavazzi, F., and M. Pagano, "Confidence Crises and Public Debt Management," in R. Dornbusch and M. Draghi, eds. Public Debt Management: Theory and History, Cambridge: Cambridge University Press, 1990.

Grossman, H. I., and J. B. van Huyck, "Sovereign Debt as a Contingent Claim: Excusable Default, Repudiation, and Reputation," American Economic Review, 78, 1988, pp. 1088-1097.

Kehoe, P. J., and F. Perri, "International Business Cycles with Endogenous Incomplete Markets," Econometrica, 70 (3), 2002, pp. 907-928.

Kletzer, K. M., "Sovereign Bond Restructuring: Collective Action Clauses and Official Crisis Intervention," in Andrew Haldane, ed. Fixing Financial Crises in the 21st Century, London: Routledge, 2003.

, "Sovereign Debt, Volatility and Insurance," Eighth Annual Conference of the Central Bank of Chile, Economia Chilena (The Chilean Economy), 2005 (forthcoming).

— 2000, pp. 621-639.

Kocherlakota, N. R., "Implications of Efficient Risk Sharing without Commitment," Review of Economic Studies, 63 (4), 1996, pp. 595-609.

Lucas, R. E., Jr., and N. L. Stokey, "Optimal Fiscal and Monetary Policy in an Economy without Capital," Journal of Monetary Economics, 12, 1983, pp. 55-93.

Missale, A., and O. Blanchard, "The Debt Burden and Debt Maturity," American Economic Review, 84, 1994, pp. 309-319.

Persson, T., and L. E. O. Svensson, "Time-Consistent Fiscal Policy and Government Cash-Flow," Journal of Monetary Economics, 14, 1984, pp. 365-374.

Thomas, J., and T. Worrall, "Self-Enforcing Wage Contracts," Review of Economic Studies, 55, 1988, pp. 541-553.

— Principal-Agent Model," Journal of Economic Theory, 51, 1990, pp. 367-390.

Townsend, R. M., "Optimal Contracts and Competitive Markets with Costly State Verification," Journal of Economic Theory, 21 (2), 1979, pp. 265-293.

Wright, M., "Reputations and Sovereign Debt," mimeo, Department of Economics, University of Chicago, 2001.

Zhu, X., "Optimal Fiscal Policy in a Stochastic Growth Model," Journal of Economic Theory, 58, 1992, pp. 250-289. 


\section{Comment}

\section{JEROMIN ZETTELMEYER ${ }^{19}$ \\ International Monetary Fund}

This is a very good paper that rigorously explores some of the joint implications of financial integration and limited enforcement of cross-border borrowing contracts. My comment makes two points. First, although there is nothing in the paper that makes it specifically a model of emerging markets, the model seems to describe the behavior of emerging market economies better than that of advanced economies, for which the policy constraints derived in the model do not generally appear to bind. That in itself is interesting, as it raises the question of why advanced economies are different. Second, as an exploration of the costs, benefits, and effects of financial integration on emerging market countries, the model is quite restrictive, looking only at a subset of the issues. Hence, paradoxically, although the model evokes problems that one associates mainly with emerging market countries, it takes a narrow view of the costs and benefits of financial integration that seems justifiable mainly for advanced economies.

Before elaborating on these ideas, it is useful to summarize the model's main predictions. In essence, the paper argues that financial integration-open capital accounts_ can place tight constraints on both fiscal and monetary policies (even under a floating exchange rate regime). Fiscal policy is constrained because deficits can only be financed within limits. For sufficiently high debt levels, taxes will have to be raised in response to domestic shocks-represented in the model as shocks to government spending-and eventually repayments may have to be renegotiated. Monetary policy is constrained, because in the presence of nominal debt inflation determines the real value of debt service; hence, an unexpected increase in inflation amounts to implicit default, with repercussions for future lending. What generates these constraints is the combination of three assumptions: financial openness, which implies that the government can tap savings (domestic or foreign) only if it offers an appropriate return; sovereignty, which puts a limit on the total amount that a country can borrow without being tempted to default; and incomplete information about country fundamentals, which implies that investors do not know whether failure to repay in full can be justified by a bad shock or whether it indicates an attempt to repudiate debt.

To these implications, one might add a third one, which is not worked out in the model but follows from the same logic: procyclical fiscal policy. Imagine that output is stochastic, and that taxes depend on output. When the economy is in a creditconstrained state, as may occur if past shocks have led to a high level of debt, a negative output shock cannot be smoothed by allowing the deficit to rise; it must be offset through higher tax rates or lower spending. More sophisticated versions of this

19. I thank Kenneth Kletzer and Olivier Jeanne for discussions on the subject. The views expressed in this comment are those of the author and do not necessarily represent those of the International Monetary Fund (IMF) or IMF policy. 
argument are possible; in particular, fiscal policy could become procyclical even when the government is not yet credit constrained, but its debt is viewed as risky, since governments may want to avoid burdening themselves with additional expensive debt (Guerson [2003]).

These implications ring true for emerging market economies, where procyclical fiscal policy is the norm (Gavin et al. [1996] and Talvi and Vegh [2000]), debt restructurings are frequent, and lack of inflation credibility is often a barrier to issuing local currency debt. But advanced economies seem to act differently: they have not defaulted since the 1930s, they engage in countercyclical fiscal policy, and they generally behave as if they were not credit constrained. As far as monetary policy goes, the model offers an interesting interpretation of why countries may seek to avoid inflation spikes, namely, to avoid rattling the debt markets. However, avoiding inflation spikes is also consistent with the declared objective of monetary policy in virtually all advanced countries, namely, to stabilize inflation at low levels, which may be optimal for reasons quite unrelated to international borrowing. Hence, it seems unlikely that reputational concerns in credit markets impose a binding constraint on monetary policy in these countries, in the sense that policymakers may be forced to refrain from actions that they would otherwise like to take.

Hence, the model appears useful mainly as an exploration of macroeconomic constraints faced by financially integrated developing countries. For this class of countries, however, we may want to consider a somewhat broader range of costs and benefits of financial integration than is emphasized in the paper. Consider first the potential costs. A superficial reading of the paper might give the impression that the costs of integration are the tighter constraints imposed by globalization on macroeconomic policy - in other words, a loss of control or flexibility. However, this is not the case, at least not in a welfare sense, as there are no welfare costs of integration in the model. The only potential cost associated with open capital accounts is the need to periodically renegotiate one's debt; however, renegotiation is assumed to be efficient. Granted, in a state of financial autarky, macroeconomic policies might appear to be less constrained: monetary policymakers will not have to worry about repercussions in credit markets, and fiscal policy could perhaps tap domestic savings more easily. But none of these policy actions would serve to improve welfare, since in the paper's model any welfare benefits of macroeconomic policies operate via improved risk sharing with the outside world. Fiscal policy, for example, is useful only as a channel for allowing external borrowing, from which some households are excluded by assumption. Government borrowing from domestic households plays no role, since the only objective of fiscal policy is to smooth the consumption of just those households.

Hence, there is no sense in this paper that emerging markets could make themselves worse off by integrating financially. Note that this is likely to remain true even if the paper is extended in some ways that might be natural based on the current model, for example, by introducing explicit costs to renegotiations. Even with costly renegotiation, financial integration allows some risk sharing while autarky does not; hence, integration remains desirable (though it might lead to less foreign borrowing and, hence, less risk sharing, compared with the case in which renegotiations are 
not costly). And even if monetary policy is given an explicit output-smoothing role in the model, so that a constraint on the conduct of monetary policy might be a real disadvantage, it is not clear from the model that financial integration would, in fact, constrain the monetary authorities in their output-smoothing role. The monetary authorities may not have to resort to inflation surprises to smooth business cycles.

The potential benefits of integration are also defined fairly narrowly. The only benefit considered is consumption smoothing via foreign borrowing. But based on calibrated models, this benefit-which could be regarded as the counterpart of the welfare losses arising from output fluctuations at the business-cycle frequency, though it is not modeled in this way in the paper-does not appear to be very large. Sovereign debt models relying on this channel alone imply debt ceilings of at least one order of magnitude below the debt levels that are observed in real life. For example, Arellano and Heathcote (2003) argue that if exclusion from future borrowing were the only channel through which defaulters could be sanctioned, countries could sustain debt levels on the order of only 1-3 percent of their GDP.

As the paper acknowledges in its introduction, a broader view of the possible implications of financial integration for emerging market countries would consider both bigger potential costs and larger potential benefits. On the cost side, the most obvious candidate, familiar from the debate following the Mexican and Asian crises, is that financial market integration exposes developing countries to sudden capital flow reversals that can lead to sharp and painful drops in output. Two ideas play a role here. First, international capital markets can be fickle; they may shut out emerging market borrowers precisely when they are needed most. Compared with the advanced countries, emerging market access to international capital is unstable, for reasons that may have to do with a deep lack of institutional credibility (Rajan [2004]). Second, international capital markets may occasionally be a source of problems, exposing countries to new types of shocks-shocks to international interest rates or risk preferences, and contagion from other emerging market crises. In light of balance-sheet mismatches or other financial frictions, these can have very large adverse effects on emerging market economies, and self-fulfilling runs may become possible (see Arellano and Mendoza [2002] and Jeanne and Zettelmeyer [2004] for recent surveys).

On the benefits side, two potential benefits of financial integration (in addition to risk sharing) have been discussed in the literature. One is the old argument that, with open capital accounts, capital can flow to where it is needed most-that is, to countries where there is relative capital scarcity. But when examined more closely, the potential welfare gains associated with this type of convergence appear small (Gourinchas and Jeanne [2004]). The intuition behind this result is that, in a neoclassical growth framework, all that financial integration does is enable a faster transition to a country's long-term growth path. Without financial integration, if the long-run path of GDP remains the same, convergence just takes longer as capital accumulation needs to be financed through domestic savings. To have truly large welfare effects, financial integration would need to have an impact on steady-state productivity rather than just the speed of transition. Some recent papers have discussed the possibility of such an effect, focusing on the potential link between 
open capital accounts and better government policies (Tornell and Velasco [1992] and Gourinchas and Jeanne [2002]). The empirical evidence on this link is mixed so far (Tytell and Wei [2004]).

To conclude, financial integration does seem to impose strong constraints on macro policies in emerging market economies - both in ways suggested by the author's paper, and beyond. In contrast, for advanced economies, these constraints generally do not appear to be binding. As pointed out by Kearns (2005), one explanation for this difference could be the more volatile economic environment in emerging market countries, which would lead to lower debt limits. Another reason, outside the paper's model, could be better institutions and, hence, higher credibility for a country's efforts to adjust to shocks without going into crisis. Finally, the costs and benefits of financial integration for emerging market economies are much more complex than modeled in the paper, and whether the benefits outweigh the costs is still a matter of debate. However, to the extent that financial integration is partly endogenous to trade integration and economic development, the real policy issue may not be making a clean choice between financial autarky and integration, but rather whether financial integration should be resisted at the possible expense of new costs or distortions.

\section{References}

Arellano, Cristina, and Jonathan Heathcote, "Dollarization and Financial Integration," mimeo, University of Minnesota and Georgetown University, 2003.

— Equilibrium Business Cycle Framework for Emerging Markets Crises," NBER Working Paper No. 8880, National Bureau of Economic Research, 2002.

Gavin, Michel, Ricardo Haussmann, Roberto Perotti, and Ernesto Talvi, "Managing Fiscal Policy in Latin America," IADB Working Paper No. 325, Inter-American Development Bank, 1996.

Gourinchas, Pierre-Olivier, and Olivier Jeanne, "On the Benefits of Capital Account Liberalization for Emerging Economics," mimeo, University of California, Berkeley, 2002.

, "The Elusive Gains from International Financial Integration," IMF Working Paper No. 04/74, International Monetary Fund, 2004.

Guerson, Alejandro, "On the Optimality of Procyclical Fiscal Policy When Governments Are Not Credible," unpublished Ph.D. thesis, George Washington University, 2003.

Jeanne, Olivier, and Jeromin Zettelmeyer, "'Original Sin,' Balance Sheet Crises and the Roles of International Lending," in Barry Eichengreen and Ricardo Hausman, eds. Other People's Money: Debt Denomination and Financial Instability in Emerging Market Economies, Chicago: University of Chicago Press, 2004 (also available as IMF Working Paper No. 02/234, International Monetary Fund, 2002).

Kearns, Jonathan, "Comment on 'International Financial Integration, Sovereignty, and Constraints on Macroeconomic Policies," Monetary and Economic Studies, 23 (S-1), Institute for Monetary and Economic Studies, Bank of Japan, 2005, pp. 191-194 (this issue).

Rajan, Raghuram, "Dollar Shortages and Crises," NBER Working Paper No. 10845, National Bureau of Economic Research, 2004.

Talvi, Ernesto, and Carlos Vegh, "Tax Base Variability and Procyclical Fiscal Policy," NBER Working Paper No. 7499, National Bureau of Economic Research, 2000.

Tornell, Aaron, and Andrés Velasco, "The Tragedy of the Commons and Economic Growth: Why Does Capital Flow from Poor to Rich Countries?” Journal of Political Economy, 100 (6), 1992, pp. 1208-1231. 
Tytell, Irina, and Shang-Jin Wei, "Does Financial Globalization Induce Better Macroeconomic Policies?” IMF Working Paper No. 04/84, International Monetary Fund, 2004.

\section{Comment}

JONATHAN KEARNS

Reserve Bank of Australia

The paper presents an elegant model that is both parsimonious and transparent. It provides a useful framework for examining the debt levels that countries can carry in a model in which sovereigns can default and taxes are smoothed intertemporally. By considering only that part of consumption that cannot be smoothed directly by consumers, the model transforms a familiar consumption-smoothing problem into a tax-smoothing problem. As someone who does not have a lot of experience in this area, I learned a lot from reading the paper. While the model is not empirical, and obviously must make many assumptions to be tractable, I personally find that it is useful to consider theoretical models in the light of the real-world phenomena they represent. My comments address the paper from this perspective.

The core of the paper is the derivation of debt thresholds when there is an informational asymmetry. There are three regions for debt levels. Below the debt level $\widetilde{W}$, there is no probability of default next period. The country can borrow as much as it needs at the risk-free interest rate. In the next region, between $\widetilde{W}$ and $\bar{W}$, there is some probability that the shock next period will be so large that the government will not be able to repay. In this region, the country can still borrow, but at a higher interest rate that incorporates a risk premium. A country in this region is at risk of default, in part because the higher interest rate places greater demand on fiscal resources. The final region is given by $\bar{W}$, the country's maximum equilibrium debt level. The country cannot borrow any more, and in bad states of the world cannot make debt repayments.

As a first pass at relating the model to the real world, we can consider what types of countries are in which regions. The model makes no assumptions about the country represented, and so can be applied to both developed and developing countries. Indeed, the model can produce great diversity of default histories and risk premiums, as witnessed in the real world. Developed countries logically fit in the first region. Their shocks are small enough relative to their debt threshold $\widetilde{W}$ that they can borrow with effectively no risk premium and do not default. Some emerging market economies are also fortunate enough to be in this region. Other emerging market economies are in the second region. They pay a risk premium and occasionally have debt restructuring or outright default.

But the fact that emerging markets are in the higher debt region does not necessarily mean that they have more debt. Debt thresholds can differ for each country. Indeed, the paper notes that in generalizations of the model, the debt thresholds would depend on domestic savings, investment, consumption, and production. One feature of the model already lends itself to understanding different debt thresholds for different countries. The more volatile is the exogenous shock (government 
expenditure), the lower will be $\widetilde{W}$, the threshold at which debt becomes risky. While there are obviously limits to interpreting this shock too literally, in many developing economies it is clear that government revenue is more volatile (often because it is tied to commodity prices and the revenue base is narrower), and that macroeconomic shocks are larger and political uncertainty greater. Temporary illiquidity can also be a big factor in sovereign defaults, and a surprisingly large shock, $g$, can easily be interpreted in this way. Also, if the tax base is narrower in a developing country-so that changes in the tax level are more distortionary and the output function $Y(T)$ which depends on taxes is more concave-then this developing country will try harder to smooth taxes. To do this, it needs to take on more debt in response to a bad shock. All of these factors can widen the range (between $\widetilde{W}$ and $\bar{W}$ ) in which an economy is at risk of default and so must pay a risk premium. They can then explain why developing countries pay higher interest rates and default more frequently.

Another feature of the model that matches history is that those countries which default are likely to do so repeatedly. A country that recovers from default, because it experiences a sequence of small shocks, will still have debt near the top of the default-risk region and so will be living on the edge. A few bad shocks, and it can slip back into the default region.

Seen in this light, the debt thresholds in the model draw a nice parallel to the empirical work on debt intolerance by Reinhart, Rogoff, and Savastano (2003). These authors conclude that macroeconomic instability, a weak fiscal structure, and weak financial systems can lead to lower sustainable levels of debt. It is relatively easy to relate these concepts to the determinants of the thresholds in the present paper. Reinhart, Rogoff, and Savastano (2003) also find that countries with lower debt tolerance have a history of default and high debt-to-GDP ratios. These two variables are also key explanators of the likelihood of default in this paper. So on this front, the model seems to mesh nicely with empirical work.

In some other respects, the model can also be related to the real world without stretching the imagination too much. In the asymmetric information equilibrium, countries issue regular bonds rather than state-contingent bonds. While there are seemingly many benefits to proposals for state-contingent lending (for example, through bonds linked to GDP or commodity prices), in practice regular bonds are still the norm. So perhaps the reality is, as the paper suggests, that regular bonds act as implicit state-contingent debt. In this interpretation, it is common knowledge that renegotiation or default will occur in bad states. But creditors accept this because of the higher interest rates in good states.

In the paper, equilibrium is sustained without resorting to exogenous penalties because lenders will withhold credit from defaulters until compensation is paid. While the equilibrium is clearly dependent on this assumption, I do not take this to mean that the main conclusions of the model would be overturned if other explanations of sovereign repayment (such as trade or credit sanctions, reputation outside credit markets, or legal sanctions) turned out to be more relevant empirically. What is important is that sovereigns have some incentive to repay their debts. Intuitively at least, the implications for debt levels would remain. 
However, there are limits to interpreting the model as an explanation of countries' actual experiences with default, and I think some of these come through in the applications considered in the paper. In the model, lending is countercyclical, and countries borrow more when they experience a bad shock, at least up until they are at their debt limit. In practice, at least for emerging markets, the procyclicality of capital flows is well established and a challenge for macroeconomic management. The fact that capital flows typically dry up when a country needs them most presumably increases their risk of default.

Another limitation comes through in the dynamics of the game. While the model has an infinite horizon, I see it more as a one-shot game, as it does not incorporate the dynamics that seem important in practice. There are no costs of defaulting (other than the need to compensate creditors for their forgone interest). But in the real world, the debtor faces substantial costs of default, including lost output and investment, and the potential weakening of the financial system and political institutions. The costs to the creditor of default are also substantial with write-downs in excess of 50 percent not uncommon, at least in the recent past. The nature of these costs is likely to greatly change the dynamics of the system. Countries that have never defaulted will attempt to maintain that record at great domestic cost. For example, during the 1930s Great Depression, Australia's debt-to-GDP ratio peaked at 200 percent and interest payments at around 30 percent of export revenue. Despite the dire economic situation, the government implemented harsh policy measures, including tax increases and a 20 percent reduction in expenditures, because the top priority of economic policy was avoiding default on foreign debt. The long-run benefits of these actions are quite clear, with this commitment contributing to Australia now being able to borrow abroad in Australian dollars, a topic I have explored in work with Ricardo Caballero and Kevin Cowan (Caballero, Cowan, and Kearns [2004]). Another factor complicating dynamics in the real world is that many developing countries issue debt with a much longer horizon than the length of crisis episodes, which we might consider as one period in the model..$^{20}$ So the real world does not reduce to a repeated game, but has greater continuity.

The paper ties debt and default to monetary policy by suggesting that inflating away debt in bad states is one way that countries can turn their regular bonds into implicit state-contingent loans. Yet in practice, few countries are able to issue debt abroad in their own currency, and those that can seem to be at very little risk of default. This mechanism is more relevant for domestic debt, but even here it seems to be limited, since countries that have a history of default often have much of their domestic debt indexed, for example, to short-term interest rates or inflation. Alternatively, when countries are able to borrow domestically in their own currency, the debt has such a short horizon that the ability of the government to reduce its real value through inflation is limited and interest rates are high enough to compensate

20. Given the repeated nature of the equilibrium game and the distributional assumptions about the shock, it seems logical to interpret a time period in this model as being the several years that may encompass a financial or fiscal crisis episode, which is still shorter than the length of some emerging market debt. 
ex ante for the additional default risk. It seems that markets do not trust governments to use this unilateral contingency tool, and so they have switched it off. ${ }^{2 l}$

Overall, the model provides a nice framework for considering government saving (or dissaving) decisions and how their interaction with the inability to enforce debt contracts of sovereign nations generates different regions of debt behavior. It can also match many stylized facts about debt default. But as with most models, the need to keep it tractable limits its applicability to studying many real-world issues, particularly the dynamics of debt and default.

\section{References}

Caballero R., K. Cowan, and J. Kearns, "Fear of Sudden Stops: Lessons from Australia and Chile,” NBER Working Paper No. 10519, National Bureau of Economic Research, 2004 (also presented at the Financial Dedollarization Conference, Inter-American Development Bank, December, 2003).

Reinhart C. M., K. S. Rogoff, and M. A. Savastano, "Debt Intolerance," Brookings Papers on Economic Activity, 1, 2003, pp. 1-74.

\section{General Discussion}

Kenneth Kletzer agreed with the comments made by the discussants and emphasized two points: the applicability of his model to non-emerging market countries and issues related to monetary policy. Regarding the applicability to non-emerging markets, Kletzer first acknowledged that the feature of procyclical fiscal policy in the model seemed to fit emerging market countries but added that this feature, which was difficult to obtain from consumption-smoothing models, was not the emphasis of his paper. Instead, he emphasized that part of the purpose of his paper was to focus on industrialized countries in a way that had not been done in the sovereign debt literature.

Regarding the issues related to monetary policy, Kletzer stated that the incomplete information structure adopted in his model made the fiscal incentives of the government consistent with the incentives for monetary stability-a feature often observed in industrialized countries.

Responding to Jonathan Kearns' comment, Jeromin Zettelmeyer added that emerging markets might be accumulating debt close to the limit because they were faced with highly volatile external shocks. Furthermore, by pointing out that these external shocks are observable, Zettelmeyer questioned why there were no contingent claims conditioned upon those external shocks and asked where the information asymmetry was coming from. Kearns responded that there was a tendency toward information asymmetry in a government's fiscal and taxation policy mainly for political reasons.

In the general discussion, acknowledging the characterization of private information by Kearns, Charles L. Evans (Federal Reserve Bank of Chicago) asked about the source of private information for the United States or other large economies where the

21. Of course, there are also instances where domestic agents are obliged or coerced to hold domestic currency debt instruments. 
market participants pay close attention to all the relevant information pertaining to fiscal and monetary policies. Kletzer noted that there might not be much private information in the case of the United States. As for the emerging markets, Kletzer stated that an example of private information was the government officials' intentions regarding the future policy course, which were not revealed to the market participants. Hiroshi Fujiki (Bank of Japan) suggested that it might be interesting to think about an explanation for the notion of "original sin" in the context of this particular model. Kletzer responded that the government assumed in this model would be forced to issue debt denominated in a foreign currency or indexed debt unless it achieved the reputational equilibrium. In this regard, Kletzer also argued that a government could earn a reputation by issuing debt in foreign currencies or indexed debt because it might be very costly to renegotiate the debt in foreign currencies or to renege on indexation of domestic debt.

Several questions were raised regarding the yield on government debt. Observing that yield on debt is equal to the discount rate despite the existence of a government's default risk in the model, Naohiko Baba (Bank of Japan) pointed out that the setup of the model made the creditors risk neutral. He questioned what would happen if we allowed for the existence of risk-averse creditors. David H. Bowman (Board of Governors of the Federal Reserve System) questioned how we should reconcile the implications of the model with the fact that the governments of emerging markets were constrained when rolling over short-term debt and the sovereign spreads were constantly in motion. Kletzer responded that, without the self-enforcement constraint, yield on government debt would be below the discount rate under the general equilibrium setting and would be equal to the discount rate if the government were faced with the two-sided constraints. In addition, Kletzer pointed out that yields on debts that were frequently rolled over were highly volatile, especially in the emerging markets. Appealing to the linkage between the volatility of the yields and the disclosure of public information, Kletzer commented that the symmetric information models with a stochastic process proxying the payoff relevant information disclosure might better explain the volatility of the yields.

Regarding the procyclical fiscal policy for emerging markets, Erdem Başçi (Central Bank of the Republic of Turkey) stated that a primary surplus would be an increasing function of the debt ratio and conjectured that the model would imply a procyclical fiscal policy by introducing default cost. Kletzer responded that the procyclicality of fiscal policy could occur when government was relying on a noncontingent bond as a debt instrument and repayment was made with certainty. While acknowledging the idea of introducing default cost, Kletzer noted that such an idea is surprisingly difficult to implement. 
